\section{Discussion}

Direct damage to coronary arteries (intimal tears, atheromatous plaque fissuring or coronary artery rupture) ${ }^{1}$ can occur following non-penetrating chest trauma. In general, the trauma is of severe magnitude; reports in the literature most commonly describe cases involved in road traffic accidents. ${ }^{2,3}$ In most cases underlying atheromatous coronary artery disease is presumed to be present, since angiographic imaging is generally not available. Where no atheromatous disease is evident, arterial occlusion resulting from intimal tears has been described. ${ }^{2}$ Cases where angiography is undertaken immediately after initial presentation appear to be rare. This case is unusual in that the chest trauma was of considerably smaller magnitude than is usually the case and occurred in a 'controlled' operative situation. Furthermore, coronary arteriography was undertaken within 30 minutes of the onset of

1 Allen RP, Liedtke AJ. The role of coronary artery injury and perfusion in the development of cardiac contusion secondary to non-penetrating chest trauma. F Trauma 1979; 19:

2 Pringle SD, Davidson KG. Myocardial infarction caused by coronary artery damage from blunt chest injury. Br Heart $\mathcal{F}$ deficiency 1987; 57: 375-6. symptoms and revealed extensive thrombus within the right coronary artery.

Thrombus formation in otherwise normal coronary arteries secondary to catecholaminemediated spasm is a rarely described phenomenon, ${ }^{4}$ but is unlikely to have been a factor in our patient since no electrocardiographic ST segment changes were apparent during the course of his general anaesthesia. Microscopic intimal tears, not visible on angiography, may have precipitated thrombus formation in this case. The relatively low magnitude of chest trauma suggests that this phenomenon may be a contributory factor in some cases of perioperative myocardial infarction following cardiothoracic surgery. Thus in patients presenting with electrocardiographic features of acute myocardial infarction following blunt chest trauma (including 'controlled' surgical trauma) early coronary angiography should be considered.

3 Pifarre R, Grieco J, Garibaldi A, Sullivan HJ, Montoya A, Bakhos $M$. Acute coronary artery occlusion secondary to blunt chest trauma. $\mathcal{F}$ Thorac Cardiovasc Surg 1982; 83: 1225.

4 Vincent GM, Anderson JL, Marshal HW. Coronary spasm producing coronary thrombosis and myocardial infarction. $N$ Engl f Med 1983; 309: 220.
Central Middlesex

Hospital, Acton Lane, London NW10 7NS, UK

A Steuer

DJ McCrea

CB Colaco

Accepted 13 November 1995

\title{
Primary Sjogren's syndrome, ulcerative colitis and selective IgA deficiency
}

\author{
A Steuer, DJ McCrea, CB Colaco
}

\begin{abstract}
Summary
A 24-year-old man with primary Sjogren's syndrome presented with xerophthalmia, xerostomia, and marked parotid swelling. He had a previous history of selective IgA deficiency and ulcerative colitis treated with sulphasalazine. Immunosuppression and withdrawal of sulphasalazine resulted in rapid resolution of the parotitis and disappearance of autoantibodies. A possible role for sulphasalazine in the induction of autoimmunity in this case is discussed.
\end{abstract}

Keywords: Sjogren's syndrome, ulcerative colitis, IgA deficiency

Primary Sjogren's syndrome is a chronic autoimmune disease of unknown aetiology predominantly affecting women in middle age. Ulcerative colitis has been rarely reported in association with Sjogren's syndrome, however both conditions may occur more often in the presence of selective IgA deficiency. We report a patient with ulcerative colitis who developed Sjogren's syndrome in the presence of selective IgA deficiency whilst on long-term sulphasalazine treatment and suggest a role for the sulphasalazine in the development of autoimmunity.

\section{Case report}

An 18-year-old Asian man presented in April 1988 with a haemorrhagic colitis. Routine haematological and biochemical profiles were normal, though the erythrocyte sedimentation rate (ESR) was raised at $65 \mathrm{~mm} / \mathrm{h}$. Colonic biopsy confirmed the typical histological features of ulcerative colitis. The patient was treated with low-dose steroids which were withdrawn after six months and sulphasalazine $1 \mathrm{~g}$ bid. He maintained a reasonable remission with only occasional flares of active colitis.

In July 1994 he presented with swollen parotid, submandibular and lacrimal glands, widespread cervical lymphadenopathy, xerostomia, xerophthalmia and myalgia. Schirmer's test (strips for measuring tear production) was dry (right eye $4 \mathrm{~mm}$, left $6 \mathrm{~mm}$ after five 
minutes). Ophthalmic assessment showed evidence of mild retinal vasculitis but no other physical abnormalities. A full blood count, renal and liver function were normal. Other investigations; ESR $48 \mathrm{~mm} / \mathrm{h}$, C-reactive protein $2 \mathrm{mg} / \mathrm{ml}$ (normal range $<10$ ), serum angiotensin-converting enzyme (ACE) $27 \mathrm{IU} / 1$ (12-80), antinuclear antibody (ANA) $1: 320$ diffuse pattern, double-stranded DNA (dsDNA) $1: 160$, extractable nuclear antigen negative, rheumatoid factor (RF) negative. Complement levels were low, C3 $0.53 \mathrm{~g} / 1$ (0.70-1.70), C4<0.08 g/1 (0.20-0.65), cryoglobulins not detected. IgG $25.0 \mathrm{~g} / 1$ (5.4-16.1), $\mathrm{IgA}<0.07 \mathrm{~g} / 1(0.8-3.4)$ and $\operatorname{IgM} 0.54 \mathrm{~g} / 1(0.5-$ 2.0 ). Chest $X$ ray was normal and a mantoux test negative. Biopsy of a cervical lymph node showed reactive changes only and a lip biopsy showed a dense lymphocytic infiltrate of the minor salivary glands consistent with Sjogren's syndrome. The patient possessed a slow acetylator phenotype.

He was commenced on prednisolone $20 \mathrm{mg}$ and azathioprine $100 \mathrm{mg}$ and sulphasalazine was stopped. Six months later dsDNA was negative and ANA positive to a titre of $1: 80$. One year later the ANA was negative (though RF was $1: 160$ ), the parotid swelling resolved and the systemic symptoms are well controlled on prednisolone $5 \mathrm{mg}$ daily. $\mathrm{C} 4$ remains low at $0.14 \mathrm{~g} / \mathrm{l}$ and $\mathrm{IgA}$ is less than $0.07 \mathrm{~g} / 1$.

\section{Discussion}

Although Sjogren's syndrome and ulcerative colitis are both relatively common conditions, their coexistence has rarely been described. ${ }^{1,2}$ IgA deficiency, the commonest form of primary immunodeficiency (occurring in 1/700 in the UK), is considered a risk factor of organspecific and systemic autoimmune disease. ${ }^{3}$ An association with systemic lupus erythematosus ${ }^{4}$ and juvenile rheumatoid arthritis ${ }^{5}$ has been established. In Sjogren's syndrome and ulcerative colitis few cases have been reported, however, reduced mucosal defence in IgA deficiency may be a simple predisposing factor to chronic submucosal inflammation and immunostimulation.

1 Triantalillidis JK, Roussou P, Manousos ON, Dadioti P, Nicolakis D. Ulcerative colitis and Sjogren's syndrome in the same patient: report of two cases and review of the literature. Ital f Gastroenterol 1994; 26: 299-302.

2 Johnson CD. Obstructive jaundice in a patient with ulcerative colitis, Sjogren's syndrome and sarcoidosis. $\exists R$ Soc Med 1989; 82: 362 .

3 Liblau RS, Bach J-F. Selective IgA deficiency and autoimmunity. Int Arch Allergy Immunol 1992; 99: 16-27.

4 Cassidy JT, Burt A, Petty R, Sullivan DB. Selective IgA deficiency in connective tissue diseases. N Engl f Med 1968; 280: 275 .

5 Barkley DO, Hohermuth HJ, Howard A, Webster ADB, Ansell BM. IgA deficiency in juvenile chronic polyarthritis. f Rheumatol 1979; 6: 219-24.
Sulphasalazine has been associated with lupus-like syndromes in patients treated for inflammatory bowel disease and, more recently, in rheumatic disease. ${ }^{6}$ Sulphasalazine therapy is also an iatrogenic cause of selective o IgA deficiency and in one study occurred in $3 \%$ of patients between eight and 20 weeks after starting treatment. ${ }^{7}$ It may have predisposed our patient to autoimmune disease, but $\stackrel{\mathbb{Q}}{\Omega}$ we feel the persistence of low levels of IgA one $C$ year after drug withdrawal makes this less $\overrightarrow{\vec{F}}$ likely. In contrast to other forms of druginduced lupus, sulphasalazine-treated patients often develop high-affinity antibodies to $\frac{\bar{N}}{\mathrm{~N}}$ dsDNA which disappear on drug withdrawal, $\overparen{\Phi}$ may be associated with hypocomplementaemia and may take many months to resolve. This $s$ patient with Sjogren's syndrome was atypical in $\overrightarrow{0}$ being a young male, possessing doublestranded DNA antibodies (normally associated with lupus), in the absence of extractable $\bar{\theta}$ nuclear antigen (in particular Ro and $\mathrm{La}$ ), the 3 marked hypocomplementaemia and disappearance of auto-antibodies a year after drug oo withdrawal, though immunosuppressive therapy was continued throughout. It is conceiva- $\overrightarrow{0}$ ble that treatment with sulphasalazine may have contributed to the induction of autoim- $]$ munity in our patient, but to our knowledge no case of primary Sjogren's syndrome has been reported due to sulphasalazine therapy, की although of course it often occurs secondary to systemic autoimmune diseases in patients on $\notin$ sulphasalazine. Furthermore, our patient's slow acetylator phenotype may represent an additional risk factor.

The persistent low $\mathrm{C} 4$ levels in the current case, even after apparent remission, is suggestive of a non-functioning $\mathrm{C} 4$ gene, with at least one $\mathrm{C} 4$ null allele. This is known to predispose $\overline{\overrightarrow{0}}$ to idiopathic and drug-induced systemic lupus erythomatosus as well as Sjogren's syndrome. ${ }^{8}$ Furthermore, IgA deficiency is often found in association with $\mathrm{C} 4$ null alleles in patients with autoimmune disease, notably in the presence of HLA-A1, B8, DR3 haplotype, though our patient was not tissue typed.

6 Laversuch CJ, Collins DA, Charles PJ, Bourke BE. Sulphasalazine-induced autoimmune abnormalities in patients with rheumatic disease. $\mathrm{Br} \mathcal{F}$ Rheumatol 1995; 34: 435-9.

7 Farr M, Kitas GD, Tunn EJ, Bacon PA. Immunodeficiencies associated with sulphasalazine therapy in inflammatory arthritis. Br $\mathcal{F}$ Rheumatol 1991; 30: 413-7.

8 Ruddy S. Complement deficiencies and rheumatic diseases. In: Kelly WN, Harris ED, Ruddy $S$, Sledge CB Textbook of rheumatology 4 th

Saunders Co, 1993; pp 1283-9. 